\title{
THE INSURER'S DUTY TO DEFEND UNDER A LIABILITY INSURANCE POLICY
}

A standard liability insurance policy ${ }^{1}$ provides that the insurance company shall pay all sums which the insured becomes legally obligated to pay as damages because of injury caused by accident and arising, for example, out of the ownership of an automobile or the proprietorship of a bar. Coverage is limited by express exclusions. A typical example of such an exclusion is an intentional injury committed either by the named insured or at his direction. In a second provision the insurance company usually further agrees, with respect to such coverage, to defend any suit against the insured alleging such injury and seeking damages on account thereof, even if such suit is groundless, false or fraudulent. It is this duty to defend provision, so deceptive in its simplicity, that is of concern here.

To begin with, the so-called insurer's dilemma must be considered. If the insurer does not defend, the insured may suffer a larger judgment than if the insurer had been conducting the lawsuit, and the insurer may be required to pay this judgment. By relinquishing control, the insurer also runs the risk that the insured may allow a claim that appears to the insurer to be either clearly outside the policy or ambiguous as to coverage to develop into a judgment within coverage. If the insurer does defend, and the third party wins, the insurer risks being barred from later asserting that the judgment falls outside the primary coverage of the first provision. The insured, on the other hand, may be surprised to find himself facing a threat of liability under factual circumstances which he thought would compel his insurance company to defend him but which, in fact, might not. ${ }^{2}$

\section{When the Insurer Must Defend-The General Rule}

In most situations the insurer and the insured can be reliably informed of the nature of the third party's claim from the complaint and can agree on coverage: if the primary coverage provision of the policy would require the insurer to pay a judgment based on the injury alleged, it must defend; if not, it need not defend. This, the general rule, ${ }^{3}$ appears attractive because it seems to fall squarely within the "alleging such injury" language in the policy. When pleading requirements were strict and variances of proof from pleadings were not tolerated, ${ }^{4}$ such a rule might have been completely

1 For a complete specimen form of standard provisions used in automobile policies, see Patterson \& Young, Cases on Insurance 697-711 (4th ed. 1961).

2 Some texts set out the range of these various problems. E.g., GREGoRy \& Katvern, Cases on Torts 550-608 (1959); Patterson \& Young, op. cit. sipra note 1, at $596-632$.

8 Annot., 50 A.L.R.2d 458 (1956) ; 7A Appleman, Insurance Law and Practice $\S 4683$ (1962).

4 See generally Shipman, Common-Law Pleading (3d ed. Ballantine 1923). 
dependable. But today's relaxed pleading requirements, notably the Federal Rules of Civil Procedure, are designed only to put an opposing party on notice ${ }^{5}$ and offer less assurance that the third party's complaint will accurately reflect its claim or predict the basis of any relief. The ease with which amendments to the pleadings to conform to the evidence may be made, absent prejudice to an opposing party, ${ }^{6}$ would by itself be enough to make the complaint a poor measure of what is to follow. For example, the gravamen of a third party's complaint purporting to sound in intentional tort might actually be negligence. If the insured's policy covered accidental injury and excluded intentional injury, a mechanical application of the general rule might relieve the insurer of any obligation to defend and, more importantly, might have the vice of foreclosing consideration of whether the insurer's duty to defend should extend to the case.?

The factual situation just posited reveals the disadvantages of applying the general rule to a case in which the third party's complaint is clearly outside the policy. Before discussing that problem, a review of how the rule works when the complaint is not clearly outside the policy will be made. Germane to this review are those cases in which the third party's complaint either is ambiguous when read against the description of coverage in the policy or has two counts, one within the policy and the other outside it. As an example of such a case, assume that a manufacturer has insurance covering a breach of warranty on its product and that this coverage expressly extends to its retailer making the same warranty. Assume further that a third party who bought the manufacturer's product from the retailer was injured and brings an action against the retailer alleging (1) that the retailer negligently failed to inspect the product before selling it and (2) that the retailer breached its express warranty. If the alleged warranty promised no more than the manufacturer's warranty, then the third party's complaint would be partly within and partly outside the manufacturer's policy. ${ }^{8}$ Although courts might differ on the consequences of an insurer's breach of its duty to defend or on how an insurer could fulfill its duty in such a case, they would virtually all recognize the insurer's duty to

5 See, e.g., Clark, Code Pleaning 56-57 (2d ed. 1947).

6 E.g., Fed. R. CIV. P. 15(b).

7 Compare Lawrence v. Northwest Cas. Co., 50 Wash. 2d 282, 311 P.2d 670 (1957) (insurer required to pay defense costs for suit alleging alternatively negligent or intentional injury but not for earlier suit alleging only intentional injury and resulting in hung jury), with McGettrick v. Fidelity \& Cas. Co., 264 F.2d 883 (2d Cir. 1959) (insurer required to pay defense costs even though suit was one alleging intentional tort). A court's inability to rule, with only the third party's allegations before it, on the insurer's obligation to pay a possible future judgment suggests that the general rule does not always apply to threats of liability within the primary coverage. Compare Green v. Aetna Ins. Co., 349 F.2d 919 (5th Cir. 1965) (declaratory judgment that insurer has no duty to defend but that question of primary coverage liability is not foreclosed), with Smedley Co. v. Employers Mut. Ins. Co., 143 Conn. 510, 123 A.2d 755 (1956) (insurer not assessed defense costs for refusing to defend suit alleging injury outside the policy; stipulated facts did not vary from allegations).

8 Cf. Sears, Roebuck \& Co. v. Liberty Mut. Ins. Co., 199 F. Supp. 769 (N.D. III. 1961). 
defend. ${ }^{2}$ Courts reach this result by resolving any uncertainty in whether a multiple count or ambiguous complaint is one "alleging such injury" against the maker of the insurance contract, the insurer. The insurer would not be entitled, for example, to a determination of which of two alternative counts represents the third party's real claim, because the insurer has agreed to defend "even if such suit is groundless . . . ."10

Some courts have modified the extent of the insurer's duty to defend against such a multiple count or ambiguous complaint. They only require the insurer to defend until it appears that the third party's lawsuit has been confined to claims outside of policy coverage. ${ }^{11}$ The modification so stated sounds like a fair compromise, but it appears to ignore the insurer's natural tendency to confine the third party's action to claims outside of coverage as soon as possible, even at the expense of the insured's interests. ${ }^{12}$ For example, if the insurer's policy excluded injury to the insured's employees from coverage, an admission by the insurer defending the insured that an allegedly injured plaintiff was an employee at the time of the injury would place the claim outside the policy. But such an admission might harm the insured if, for instance, he did not have workmen's compensation insurance ${ }^{13}$ or if the standard of care due an automobile passenger under a guest statute turned on whether he was an employee or simply a guest.14 It is unclear how courts would reconcile the relief afforded to the insurer by this modified duty to defend rule with the waiver and estoppel doctrines. These doctrines ${ }^{15}$ bar the insurer from asserting certain policy defenses in

9 E.g., American Indem. Co. v. Sears, Roebuck \& Co., 195 F.2d 353 (6th Cir. 1952); Lee v. Aetna Cas. \& Sur. Co., 178 F.2d 750 (2d Cir. 1949) (L. Hand, J.); Continental Cas. Co. v. Reinhardt, 247 F. Supp. 173 (D. Ore. 1965) ; Moffat v. Metropolitan Cas. Ins. Co., 238 F. Supp. 165 (M.D. Pa. 1964); Lawrence v. Northwest Cas. Co., 50 Wash. 2d 282, 311 P.2d 670 (1957); Alm v. Hartford Fire Ins. Co., 369 P.2d 216 (Wyo. 1962). Contra, Stout v. Grain Dealers Mut. Ins. Co., 201 F. Supp. 647 (M.D.N.C.), aff'd, 307 F.2d 521 (4th Cir. 1962) (insured previously pleaded guilty to manslaughter; declaratory judgment that insurer not required to defend suit alleging alternatively negligent and intentional killing where court found insured had acted intentionally); see Commercial Union Ins. Co. v. Hall, 246 F. Supp. 64 (E.D.S.C. 1965) (declaratory judgment of no duty to defend based on stipulated facts); Federated Mut. Implement \& Hardware Ins. Co. v. Gupton, 211 F. Supp. 509 (E.D.S.C. 1965) (same).

10 See Alm v. Hartford Fire Ins. Co., 369 P.2d 216 (Wyo. 1962).

11 E.g., Lee v. Aetna Cas. \& Sur. Co., 178 F.2d 750 (2d Cir. 1949) (L. Hand, J.) (dictum) ; Sears, Roebuck \& Co. v. Liberty Mut. Ins. Co., 199 F. Supp. 769 (N.D. I11. 1961); Vappi \& Co. v. Aetna Cas. \& Sur. Co., 204 N.E.2d 273 (Mass. 1965).

12 See Roos, The Obligation To Defend and Some Related Problems, 13 Hastings L.J. 206, 211-13 (1961).

13 Cf. Crum v. Anchor Cas. Co., 264 Minn. 378, 119 N.W.2d 703 (1963).

14 Cf. Journal Pub. Co. v. General Cas. Co., 210 F.2d 202 (9th Cir. 1954).

15 "Waiver" is an intentional relinquishment of a known right, and "estoppel" precludes one from denying a representation relied on by another who would be prejudiced by the denial. The two doctrines in this context, however, amount to the same protection as they are applied. See generally VANCE, HANDBOOK ON THE LAW OF INSURANCE ch. 9 (3d ed. Anderson 1951); Morris, Waiver and Estoppel in Insurance Policy Litigation, 105 U. PA. L. REv. 925 (1957). Aithough they are distinguished, James v. Pennsylvania Gen. Ins. Co., 349 F.2d 228 (D.C. Cir. 1965), and cases have been held to turn on the distinction, e.g., Andover v. Hartford Acc. \& Indem. Co., 217 A.2d 60 (Conn. 1966), such distinctions become fine when knowledge of the right relinquished is inferred from the circumstances; compare Jenkins v. Indemnity Ins. Co. of North America, 152 Conn. 249, 205 A.2d 780 (1964), with Fay v. Noia, 372 U.S. 391, 439 (1963) (habeas corpus case), and Comment, 
order to prevent it from obtaining any advantage vis-à-vis the insured flowing from its conduct of the insured's defense. ${ }^{16}$

One court seems to have required the insured to show actual prejudice from the insurer's interim defense before the insured could invoke estoppel. ${ }^{17}$ In cases in which the insurer assumes the complete defense, however, the insured is not usually required to prove that he was misled or prejudiced by the insurer's defense. ${ }^{18}$ The reasons for so applying the waiver and estoppel doctrines to complete defenses seem equally applicable to cases in which the insurer assumes only part of the defense. Such a broad prophylaxis would protect both the insured and the legal profession. If the insured were in fact prejudiced by the insurer's defense, the insured would find it difficult to carry his burden of proof. His argument would be hypothetical and take the form of "but for the insurer's defense . . . ." To substantiate his hypothesis he would have to rely on evidence that might be stale, since his action on the policy against the insurer would come after the third party's action. Moreover, since his claim, if proven, would tend to discredit a member of the bar, it might not have a sympathetic reception. Most importantly, there is the danger that the insurer could profit from its position of trust at the expense of the insured. ${ }^{19}$ The

114 U. PA. L. REv. 451 (1966), and prejudice from the insurer's assumption of the defense is conclusively presumed, Pendleton v. Pan Am. Fire \& Cas. Co., 317 F.2d 96 (10th Cir.), cert. denied, 375 U.S. 905 (1963), order modified, 326 F.2d 760 (1964).

16 E.g., Pendleton v. Pan Am. Fire. \& Cas. Co., supra note 15; Jenkins v. Indemnity Ins. Co. of North America, supra note 15 . See generally 8 APPLEMAN, op. cit. supra note $3, \S 4747$; Morris, supra note 15.

17 Journal Pub. Co. v. General Cas. Co., 210 F.2d 202, 205 (9th Cir. 1954) (lower court's finding sustained by the record). See also Note, Insurance Company's Dilemma: Defending Actions Against the Assured, 2 Stan. L. REv. 383 (1950), suggesting that waiver be implied only where prejudice is shown and that waiver not be implied in any event before noncoverage is known to the insurer.

18 See Note, Liability Insurance Policy Defenses and the Duty To Defend, 68 HaRv. L. Rev. 1436, 1444-45 (1955).

19 Burish v. Dignon, $416 \mathrm{~Pa} .486,206$ A.2d 497 (1965), involved a two car collision at an intersection. An attorney retained by the insurer defended an action against the insured driver by the third party, the other driver. The insured retained another attorney in the same action to press a counterclaim against the third party. After losing, the insured argued on appeal that the trial judge had abused his discretion in allowing only the insured's attorney, and not the insurer's attorney as well, to make a summation to the jury, since there was a close factual issue. The Pennsylvania Supreme Court held that the trial judge had not abused his discretion in limiting the number of summations in behalf of the insured to the number made in behalf of the third party.

Of interest here is the question raised by what the insured's attorney planned to urge on summation. The insured's own attorney argued to the jury that the third party had been negligent and that the insured had not been contributorily negligent. The insurer's attorney was going to argue that both parties were negligent and that neither should recover. If that latter argument had prevailed, query whether the insured could have maintained an action on the policy on the theory that through a conflict of interest the insurer's attorney had prejudiced the insured's counterclaim. The insurer might have responded on two grounds: (1) It agreed only to defend certain suits against the insured and not to protect any other claims that the insured might have; and (2) the insured could have repudiated the insurance policy and refused to permit the insurer to defend.

The difficulties in such a case are much like those in the case where the same insurer has insured both parties. See O'Morrow v. Borad, 27 Cal. 2d 815, 167 P.2d 483 (1946). It has been suggested that the problems inherent in a situation like 
key figure in causing any such abuse is the insurer's attorney, who would be the one faced with the potential conflict of interest. The interest of the legal profession as a whole would seem to demand that this attorney's conduct be beyond possible reproach. ${ }^{20}$ Furthermore, once the insurer has assumed the insured's defense, the insured is encouraged, and even required by his policy, to cooperate fully with, do nothing independently of, and be completely candid with "his" attorney. Suspicion that the insurer's attorney and investigators may be building a case for the insurer at the expense of the insured might cause the insured to respond guardedly; in the long run this would be to neither party's advantage. ${ }^{21}$

The problem, then, is that in every instance in which the third party's complaint on its face is both within and outside the policy, the defending insurer has a potential conflict of interest. This potential conflict occurs whether the governing rule requires the insurer to defend throughout or to defend until the third party's action has been confined to claims outside the policy. The nub of any resolution of the problem lies in the recognition that the duty to defend can be separated into two distinct elements: (1) the insurer's right to control the insured's defense; and (2) the insurer's obligation to pay for the costs of this defense. Control, and along with it the power to "shape" the third party's claim in a manner inconsistent with the insured's interest, insofar as this is possible from a defensive posture, is the element causing a potential conflict of interest. Thus, even though there is absent in the policy any such distinction between control and cost responsibility, that absence must be balanced against the necessity of maintaining public confidence in the judicial process and requires that some sort of check be placed on the insurer's right to have its attorneys conduct the defense. ${ }^{22}$ Such a check could be created by exacting a high price for the right: the insurer would be permitted to assume the defense of an ambiguous or multiple count complaint only at the risk of later being estopped-under a strict standard-from denying coverage. ${ }^{23}$

O'Morroze could be avoided by trying each action separately. Casper, The Defense of Automobile Collision Cases by Insurers in Pennsylvania, 60 DICK. L. REv. 171 (1956). The suggestion would seem equally applicable to Burish. However, the suggestion might be limited by the effects of collateral estoppel or mandatory joinder of claims, neither of which the third party could be expected to waive in advance.

20 See Allstate Ins. Co. v. Keller, 17 Ill. App. 2d 44, 149 N.E.2d 482 (1958); Fidelity \& Cas. Co. v. McConnaughy, 228 Md. 1, 179 A.2d 117 (1962); American Employers Ins. Co. v. Goble Aircraft Specialties, Inc., 205 Misc. 1066, 131 N.Y.S.2d 393 (Sup. Ct. 1954); Perkoski v. Wilson, 371 Pa. 553, 92 A.2d 189 (1952); Note, Duty of Attorney Appointed by Liability Insurance Company, 14 ClEv.-MAR. L. Rev. 375 (1965).

21 See Chitty v. State Farm Mut. Auto. Ins. Co., 36 F.R.D. 37 (E.D.S.C. 1964) (insured may have discovery against insurer under federal rule 34 in action on policy); Henke v. Iowa Home Mut. Cas. Co., 249 Iowa 614, 87 N.W.2d 920 (1958) ; 72 HARv. L. REv. 766 (1959). But cf. Manning v. State Farm Mut. Auto. Ins. Co., 235 F. Supp. 615 (W.D.N.C. 1964) (insurer's correspondence privileged against disclosure to third party in action on the policy).

22 See Kaplan, Forbidden Retainers, 31 N.Y.U.L. REv. 914, 924-26 (1956).

23 This distinction between actual control of a defense and the obligation to pay defense costs was recognized, in effect, in an action for declaratory judgment initiated after the third party's complaint had been filed. Prashker v. United States Guar. 


\section{The EFFECT OF A JUdGMENT}

It should follow from this delicate two-fold balancing of interests that if the insurer chose to relinquish control of the defense in order to avoid a conflict of interest, it would later be free to argue that the grounds on which any judgment purports to be based are outside the policy, even though the insurer would be liable for defense costs. Nonetheless there is a split of authority. According to the better rule, whether the grounds on which a judgment against the insured was entered were within coverage would be a contestable issue. ${ }^{24}$ But some courts have held that since the insurer wrongfully breached its contractual duty to defend the insured, it should be liable for the consequences of that breach-the judgment that the insured suffered-regardless of the grounds for the judgment. ${ }^{25}$ It

Co., 1 N.Y.2d 584, 136 N.E.2d 871, 154 N.Y.S.2d 910 (1956) (insured should select attorneys and the insurer would be liable for the reasonable value of their services). In fact, any time that an insurer has refused to defend a suit which is ambiguous as to coverage and the insurer is charged with defense costs after the suit has been completed, the two elements of the duty to defend have necessarily been separated. E.g., Moffat v. Metropolitan Cas. Ins. Co., 238 F. Supp. 165 (M.D. Pa. 1964) (insurer required to reimburse the insured for the defense of a suit alleging (1) an intentional injury, which was excluded from coverage, and (2) facts within coverage). 24 Lee v. Aetna Cas. \& Sur. Co., 178 F.2d 750 (2d Cir. 1949) (L. Hand, J.); Great Am. Ins. Co. v. Ratliff, 242 F. Supp. 983 (E.D. Ark. 1965) ; Moffat v. Metropolitan Cas. Ins. Co., supra note 23.

The clearest instance of the separability of the issues of liability for defense costs and liability for the amount of judgment is the case in which the insured has suffered a judgment, had no defense expenses and seeks to hold the insurer liable for the judgment because it failed to defend, and there is no recovery. In McCarthy v. United Servs. Auto. Ass'n, 24 Misc. 2d 79, 80, 204 N.Y.S.2d 420, 421 (Sup. Ct. 1960), the court said: "The fact that defendant may have had an obligation to defend Branch or that he violated such obligation may render him liable in damages to Branch, had Branch expended money to defend himself. It does not by itself render defendant liable for the judgment. There is a distinction between liability and coverage. . ."Accord, Gedeon v. State Farm Mut. Auto. Ins. Co., 410 Pa. 55, 188 A.2d 320 (1963); see Comunale v. Traders \& Gen. Ins. Co., 50 Cal. 2d 654, 659-60, 328 P.2d 198, 201 (1958), 47 GEo. L.J. 601 (1959); 107 U. PA. L. REv. 571 (1959).

${ }^{25}$ E.g., Leonardi v. Standard Acc. Ins. Co., 212 F.2d 887 (2d Cir. 1954) (insurer liable for judgment even though it appeared that the prior court, in effect, directed a verdict against the third party on the only issue within the policy).

Using a variation of the above approach, the insured in the Gedeon case, supra note 24 , instituted a second case in federal court in a further effort to recover the amount of the judgment he had suffered. Gedeon v. State Farm Mut. Auto. Ins. Co., 227 F. Supp. 342 (W.D. Pa. 1964). This time his claim was based on the insurer's breach of its pretrial defense obligations to investigate and settle, if possible, as opposed to its obligation to defend in court, which was res judicata. The relief requested was damages in the amount of the judgment, which was greater than the policy dollar limits. The Third Circuit reversed a summary judgment for the insurer. 342 F.2d 15 (3d Cir. 1965); see King v. Automobile Underwriters, Inc., $409 \mathrm{~Pa} .608$, 187 A.2d 584 (1963).

Some secondary authorities have made broad statements to the effect that the insurer's liability for the amount of judgment categorically follows from its liability for defense costs. E.g., 7 AM. JUR. 2D Automobile Insurance \$166 (1963); Annot., 49 A.L.R.2d 694, 717 (1957) ; 14 CouCH, INSURANCE 2D \& 51:54, at 552 (1965): "The insurer's unjustified refusal to defend makes it bound to pay the amount of the judgment rendered against the insured, or of any settlement made in good faith by the insured in the action brought against him by the injured party." Seemingly relying on such statements, some courts disregard the possibility that the grounds of a judgment may be outside the policy. E.g., Sims v. Illinois Nat'l Cas. Co., 43 I1l. App. 2d 184, 193 N.E.2d 123 (1963). 
would seem that there is no causal nexus, in the usual legal sense, between the insurer's refusal to defend and the judgment that the insured suffered. If the insured's counsel were not impeached and if there were no special circumstances, the insured would have suffered the judgment in any event. Perhaps the unarticulated rationale for these decisions is that the courts are reluctant to permit an insurer to place itself in a better position by refusing to fulfill its duty to defend than it would have been in had it defended; ${ }^{26}$ if the insurer actually had defended, it might then have been estopped from asserting the policy defense that the judgment was outside the policy. This rationale is not persuasive, because the very risk which estoppel is designed to meet is not present, since the insurer has not defended.

Even accepting the "better" rule, the insurer's freedom to argue that a judgment, as entered, is not within the policy might only be a limited benefit, for while the insurer would no longer have any control over the form a judgment might take, the insured would. The shift in control avoids the insurer's conflict of interest, but with the insured controlling his own defense the insurer's interests might not be fully protected. A compromise might be collaboration. ${ }^{27}$ The presence of the insurer's attorney might tend to discourage attempts to adopt a defense strategy designed more to shape the third party's claim within coverage than to minimize loss, and his presence might improve the quality of defense.

It has been assumed so far that once judgment has been entered for the third party, the insurer may not reopen the factual basis of the judgment in defending an action on the policy. ${ }^{28}$ Although judgment rules are sometimes cited as authority for this limitation, ${ }^{29}$ neither collateral estoppel nor res judicata would seem strictly applicable, for "the rendition of a judgment in an action does not conclude parties to the action who are not adversaries under the pleadings as to their rights inter se upon matters which they did not litigate, or have an opportunity to litigate, between themselves." 30 The real reason for the limitation lies in the insurance policy itself. The insurer agrees "to pay all sums which the insured becomes legally obligated to pay as damages because of injury caused by

${ }^{26}$ Cf. Continental Cas. Co. v. Zurich Ins. Co., 57 Cal. $2 \mathrm{~d} 27,366$ P.2d 455, 17 Cal. Rptr. 12 (1961).

27 See Magoun v. Liberty Mut. Ins. Co., 346 Mass. 677, 195 N.E.2d 514 (1964).

28 See generally 8 ApPLEMAN, op. cit. supra note $3, \S 4860$. Compare UNIFORM COMMERCIAL CODE \& 2-607(5):

Where the buyer is sued for breach of a warranty or other obligation for which his seller is answerable over (a) he may give his seller written notice of the litigation. If the notice states that the seller may come in and defend and that if the seller does not do so he will be bound in any action against him by his buyer by any determination of fact common to the two litigations, then unless the seller after seasonable receipt of the notice does come in and defend he is so bound.

29 See, e.g., Shelby Mut. Cas. Co. v. Richmond, 185 F.2d 803 (2d Cir. 1950), cert. denied, 341 U.S. 931 (1951) ; Dally v. Pennsylvania Threshermen \& Farmers' Mut. Cas. Ins. Co., $374 \mathrm{~Pa} .476,97$ A.2d 795 (1953).

30 Restatement, Judgments $\$ 82$, at 384-85 (1942); cf. id. $\$ 111$; Newfane v. Merchants Mut. Cas. Co., 10 Misc. 2d 163, 169 N.Y.S.2d 576 (Sup. Ct. 1957). 
accident . . . ." The judgment in the action between the third party and the insured, of course, would show conclusively, absent collusion, that the insured has become "legally obligated." It would also seem to be conclusive within the meaning of the policy as to the legal and factual basis of why the insured has become "legally obligated." 31 If, for example, the third party had secured a judgment based on a claim of negligence, the insurer certainly could not argue that it should not be required to indemnify the insured because in fact the third party had been contributorily negligent. ${ }^{32}$ Even if the insurer could show that the third party had been contributorily negligent, the insured would still remain "legally obligated" to satisfy the prior judgment. ${ }^{33}$ Similarly, an insurer's offer to disprove

31 E.g., Connecticut Fire Ins. Co. v. Reliance Ins. Co., 208 F. Supp. 20, 27 (D. Kan. 1962) ; Wilhide v. Keystone Ins. Co., 195 F. Supp. 659, 662 (M.D. Pa. 1961) ("the defendant here is now concluded by the judgment in the prior suit so far as it determined the cause of the injury, the amount of damages sustained and the liability of the insured"); Geddes \& Smith, Inc. v. Saint Paul-Mercury Indem. Co., 51 Cal. 2d 558, 334 P.2d 881 (1959) (Traynor, J.) (judgment included additional elements of damages outside the policy for which insurer would not be liable).

A difficult case is one in which the third party seems to anticipate a policy exclusion for intentional injuries. Thus a third party might base his action on negligence, even though the insured was convicted of a criminal charge of which wrongful intent was a necessary element. If the third party is content to restrict his claim to negligence, the insurer might be concluded by a judgment within the policy. See Gould v. Country Mut. Cas. Co., 37 III. App. 2d 265, 185 N.E.2d 603 (1962). An action for declaratory judgment on the issue of primary coverage before the third party's action has been completed would probably be held premature. Green v. Aetna Ins. Co., 349 F.2d 919 (5th Cir. 1965) ; see Harbin v. Assurance Co. of America, 308 F.2d 748 (10th Cir. 1962). Contra, Stout v. Grain Dealers Mut. Ins. Co., 201 F. Supp. 647 (M.D.N.C.), aff'd, 307 F.2d 521 (4th Cir. 1962); see Commercial Union Ins. Co. v. Hall, 246 F. Supp. 64 (E.D.S.C. 1965); Federated Mut. Implement \& Hardware Ins. Co. v. Gupton, 241 F. Supp. 509 (E.D.S.C. 1965).

Three ways of attacking any judgment that the insured may suffer might be open to the insurer. In an action on the policy, a court might be persuaded to make an independent finding of fact, in disregard of the prior judgment and in recognition of the insurer's extraordinary position. See Farm Bureau Mut. Auto. Ins. Co. v. Hammer, 177 F.2d 793 (4th Cir. 1949), cert. denied, 339 U.S. 914 (1950), 4 OKLA. L. REV. 125 (1951) ; Weis v. State Farm Mut. Auto. Ins. Co., 242 Minn. 141, 64 N.W.2d 366 (1954) ; Vaksman v. Zurich Gen. Acc. \& Liab. Ins. Co., 172 Pa. Super. 588, 94 A.2d 186 (1953). However, the insurer's position actually is not so different from any case in which it maintains that a prior court misconstrued the facts. See Farm Bureau Mut. Auto. Ins. Co. v. Hammer, supra at 802 (dissenting opinion). A second way might be to persuade a court, in an action on the policy, to give some effect to the criminal judgment as well as the civil judgment. See Smith v. Andrews, 54 I11. App. 2d 51, 203 N.E.2d 160 (1964) (overruling Gould v. Country Mut. Cas. Co., supra). See generally Maguire, Weinstern, Chadrourn \& MansFIeld, Cases on Evidence 539-41 (5th ed. 1965). A recent Pennsylvania case held that the record of a defendant's prior criminal conviction conclusively established the fact of the defendant's extortion for purposes of a civil suit. Hurtt v. Stirone, $416 \mathrm{~Pa}$. 493, 206 A.2d 624, cert. denied, 381 U.S. 925 (1965). The soundest approach in an action on the policy, though, would be to pinpoint precisely what the prior judgment established. Thus, if the third party's judgment were based on negligence alone, the prior court may only have decided that as between negligence and nonnegligence the insured had been negligent. If that court did not decide that as between negligence and intentional tort the insured had been only negligent, a court in an action on the policy ought to be free to decide whether the insured had committed an intentional tort. Great Am. Ins. Co. v. Ratliff, 242 F. Supp. 983 (E.D. Ark. 1965).

32 Howe v. Howe, 87 N.H. 338, 179 Atl. 362 (1936).

33 See Hoffine v. Standard Acc. Ins. Co., 191 Kan. 63, 379 P.2d 246 (1963) (insurer precluded from maintaining that since insured had not been properly served with process, judgment was a nullity). 
an agency relationship, already established to hold the insured liable by respondeat superior, would be rejected in an action on the policy. ${ }^{34}$

The next question is how may the insurer show that the grounds of judgment were outside the policy. Although the insurer's duty to defend is determined solely by reference to the third party's complaint, this test cannot be used to determine the grounds of a judgment, for there may have been an unchallenged variance or a multiple count complaint may have developed into a judgment outside the policy. Therefore, together with the complaint, any jury charge, ${ }^{35}$ opinion and transcript would seem relevant. It is not clear whether other items of evidence would be admissible. In some cases witnesses who testified in the third party's suit have been permitted to testify in a later action on the policy without objection from counsel. ${ }^{36}$ However, since the issue is on what factual and legal grounds the prior court entered judgment, new witnesses should not be permitted to testify, for their testimony would be relevant only to what actually happened rather than to what the prior court has found happened.37 An exception might occur if a consent or default judgment more closely resembled a settlement than an ordinary judgment.

Before discussing settlements, a comment should be made on what a judgment is not competent to prove. In a recent case the insurer had refused to defend under a homeowner's policy because it claimed that the insured's property was being used for business purposes contrary to the conditions of coverage. ${ }^{38}$ The insured, after losing to the third party, sued both for defense costs and the amount of judgment. Summary judgment for the insured was sustained on appeal. The court said that "if the insured [sic] has notice of an action against the insured with respect to liability which the injury claim shows to be covered by the policy, a judgment will be conclusive whether the insurer defends or not." 39 The case seems

34 Dally v. Pennsylvania Threshermen \& Farmers' Mut. Cas. Ins. Co., $374 \mathrm{~Pa}$. 476, 97 A.2d 795 (1953); Jusiak v. Commercial Cas. Ins. Co., 11 N.J. Misc. 869, 169 At1. 551 (Sup. Ct. 1933).

35 E.g., Saragan v. Bousquet, 322 Mass. 14, 75 N.E.2d 649 (1947) (jury charge admissible to show whether the jury had found that the third party was the insured's servant or social guest) . Contra, Stefus v. London \& Lancashire Indem. Co., 111 N.J.L. 6, 166 Atl. 339 (Ct. Err. \& App.), cert. denied, 290 U.S. 657 (1933) (jury charge not admissible to support insurer's defense that injury was willful where suit alleged "carelessness, negligence and recklessness").

${ }^{36}$ In Sheehan v. Goriansky, 321 Mass. 200, 72 N.E.2d 538 (1947), the precise ground of the insured's legal obligation to the third party could not readily be determined. Judgment had been entered on a verdict returned by a jury charged with finding whether or not there had been a "willful, wanton or reckless" injury, and willful injuries were excluded from coverage. In an action on the policy, a finding was made based on the prior record and the testimony of Goriansky to which no objection was made.

37 If new witnesses should not be permitted to testify, it may follow that the possibility of new testimony from a prior witness should be enough not to permit a prior witness to testify. In any event, an exception, of course, would be a case in which the insurer defends an action on the policy on the ground that the prior court's findings were distorted by collusion between the insured and the third party. Conwell v. Indiana Ins. Co., 334 F.2d 993 (4th Cir. 1964).

38 McFadyen v. North River Ins. Co., 62 I1l. App. 2d 164, 209 N.E.2d 833 (1965).

30209 N.E.2d at 836. 
wrong. Since a judgment would not be conclusive as to whether the insurer had been seasonably notified, ${ }^{40}$ it should not be conclusive as to other questions based on other policy provisions not dealing with the liability of the insured to a third party. ${ }^{41}$ Certainly the third party usually has no proper interest in alleging that an insured defendant has paid all his premiums or that the insured's premises were not being used for business purposes. ${ }^{42}$ If this bar to the insurer's policy defenses was a penalty for wrongly refusing to defend, the case also seems unsupportable. ${ }^{43}$ The court suggested that the insurer could have protected itself by instituting an action for a declaratory judgment or by defending under a reservation of rights. ${ }^{44}$ However, if the insurer's contention were valid, the insured could not be said to have been hurt since he in no way could have been misled by any position that the insurer assumed. Therefore, the timing of the judicial determination as to whether the insured had been using his premises for business purposes should not have been thought controlling.

\section{Setrlements}

Settlements raise the same 45 and more problems. If the insured settles with the third party after the insurer has declined to defend, the basis of the insured's legal obligation is not fixed in a trial record. In one sense the basis of the insured's liability is what he or his attorney who negotiated the settlement thought it was. Mr. Justice Holmes wrote that "a sum paid in the prudent settlement of a suit is paid under the compulsion of the suit as truly as if it were paid upon execution." 46 The question here is why the sum is paid. If the insurer has refused to defend a claim within

40 E.g., Sussman v. American Sur. Co., 345 F.2d 679 (5th Cir. 1965); Muncie v. Travelers Ins. Co., 253 N.C. 74, 116 S.E.2d 474 (1960).

41 Although there might be some question as to whether the insurer or the insured had the burden of proof of a breach, see Comment, Insurance-Burden of Proof in Insurance Exception Clauses-Pleading, 40 N.C.L. REv. 138 (1961), the issue of a breach would not seem to be foreclosed.

42 See University Club v. American Mut. Liab. Ins. Co., $124 \mathrm{~Pa}$. Super. 480, 189 Atl. 534 (1937), as interpreted in Hardware Mut. Cas. Co. v. Hilderbrandt, 119 F.2d 291, 301 (10th Cir. 1941) (dissenting opinion).

43 See text accompanying notes 25-26 sitpra.

44 The suggestion was made by way of approval of Sims v. Illinois Nat'l Cas. Co., 43 I11. App. 2d 184, 193 N.E.2d 123 (1963), in which it was said: "In cases of doubt the answer is simple. [The insurer] can (1) seek a declaratory judgment as to its obligations and rights or (2) defend under a reservation of rights." Id. at 199, 193 N.E.2d at 130. However, there is some question whether an action for declaratory judgment would lie in Illinois. See McKenna, The Insurer's Dilemma: Defend Under a Non-Waiver or Disclaim and Pray, 52 InL. B.J. 918, 919 (1964). Furthermore, the insured has no obligation to permit the insurer to defend under a reservation of rights. E.g., Magoun v. Liberty Mut. Ins. Co., 346 Mass. 677, 195 N.E.2d 514 (1964).

45 Cf. Theodore v. Zurich Gen. Acc. \& Liab. Ins. Co., 364 P.2d 51 (Alaska 1961), in which the insurer's liability for the amount of a settlement was said to follow from its failure to defend, "for that which is paid in a prudent settlement of an action for damages is something which the insured has 'become legally obligated to pay' within the meaning of the insurance policy. Zurich became liable for the amount of the judgment because this was the natural consequence of its breach . . . " Id. at 55-56. ${ }^{46}$ St. Louis Dressed Beef \& Provision Co. v. Maryland Cas. Co., 201 U.S. 173, 182 (1906) (Holmes, J.). 
the policy and the insured has settled, the insurer has the burden of showing that the settlement does not represent a legal obligation within the policy or that the amount of settlement was not reasonable. ${ }^{47}$ If the third party's complaint contained alternative claims only one of which was within the policy, the insurer has the burden of showing that the legal obligation was on grounds outside the policy. ${ }^{48}$

To evaluate these approaches, it is necessary to identify the compromises that compose a settlement and to consider the possible consequences of a different approach. If the third party's claim appeared from the complaint to be partly within and partly outside the policy, the settlement figure might very well be influenced by an aggregate of the probabilities of losing on grounds within the policy and those of losing on grounds outside the policy plus the probability of paying high litigation expenses. ${ }^{49}$ On the one hand, since the insurer agrees to indemnify the insured for his legal obligations arising "because of injury" within the description of coverage, the insurer should pay no more than the sum of the dollar figures assignable to those of the various grounds for settlement within the policy. On the other hand, if the insurer were permitted to offer evidence in support of such an assignment, the effect might be that the insured would be less willing to settle a claim, unless he were confident that he could later show that the grounds of the settlement were within the policy or unless the risk of a high judgment outweighed the risk that the claim might fall outside the policy. This objection, however, cannot be fully accepted because if the insurer were not permitted to introduce evidence for the purpose of assigning the settlement figure to specific grounds, not only would policy coverage, in effect, be extended but the insured might be more willing to accept a high offer of settlement from the third party to avoid the risk of a trial that would result in a judgment on grounds clearly outside the policy.

A middle way seems best. If the insurer is given the opportunity and burden of proving that the settlement, or an identifiable portion of the settlement, must have been made on grounds outside the policy, there would be a check on the insured and at the same time the tendency otherwise to discourage settlements would be minimized, since the insurer's burden would be heavy. One case illustrates many of the settlement problems and seems to adopt this middle way. ${ }^{50}$ The third parties claimed (1) that they had been slandered, (2) that they had been assaulted by the insured

47 E.g., Boutwell v. Employers' Liab. Assur. Corp., 175 F.2d 597 (5th Cir. 1949). 48 Cadwallader v. New Amsterdam Cas. Co., $396 \mathrm{~Pa} .582,152$ A.2d 484 (1959); cf. Pittsburgh Plate Glass Co. v. Fidelity \& Cas. Co., 281 F.2d 538 (3d Cir. 1960) : Globe Indem. Co. v. Hansen, 231 F.2d 895 (8th Cir. 1956) (semble), reversing 127 F. Supp. 260 (D. Minn. 1954) (no distinction made between insurer's duty to defend based on third party's allegations and obligation to pay settlement) ; Ripepi v. American Ins. Co., 234 F. Supp. 156 (W.D. Pa. 1964). But see Baker v. American Ins. Co., 324 F.2d 748 (4th Cir. 1963).

49 See Travelers Ins. Co. v. Motorists Mut. Ins. Co., 88 Ohio L. Abs. 129, 178 N.E.2d 613 (Ct. App. 1961).

50 Employers Mut. Liab. Ins. Co. v. Hendrix, 199 F.2d 53 (4th Cir. 1952). 
landowner's game warden, and (3) that the assault was at the direction of the insured. The insurer refused to defend because the policy covered only accidental bodily injury and excluded intentional injuries inflicted at the direction of the insured. The insured's attorneys settled for a high figure out of a fear of jury prejudice, but only after the third parties had amended their complaint to delete any claim that the intentional injury was at the direction of the insured. ${ }^{51}$ The appellate court found that the insurer was liable for the insured's attorneys' fees, but reduced the liability to a reasonable amount. The court remanded to allow an apportionment to be made between damages for slander and damages for personal injury. The court made no mention of any further apportionment between damages for personal injury within coverage and those excluded from coverage. The lack of such an apportionment is consistent with placing the burden on the insurer to show that an identifiable portion of the settlement of the personal injury claims must have been made on grounds outside the policy, for the insurer did not and could not so show. ${ }^{52}$

\section{Reservations of Rights and Nonwatver Agreements}

In some cases the insurer might avoid its dilemma by defending after it has notified the insured that it is reserving certain policy defenses or after the insured has agreed not to defeat its policy defenses by raising waiver or estoppel. Both a reservation of rights and a nonwaiver agreement amount to the same protection. When the insurer assumes the insured's defense under a reservation of rights, the insured's acquiescence is given the same effect as if he had entered into a bilateral nonwaiver agreement. Under both, the insurer retains the right to press only announced policy defenses.

These devices might raise a problem of failure of consideration as well as a question of professional ethics. If the third party's allegations re-

51 Apparently, the insured did not then inform the insurer of the amended complaint and again tender the defense. The insured's failure to notify the insurer that the third party's allegations, wholly outside coverage, have been amended to fall within coverage has been held fatal to the insured's rights. Sussman v. American Sur. Co., 345 F.2d 679 (5th Cir. 1965). Such a failure is a breach of the notification requirement in the policy and does not necessarily destroy an indemnitor-indemnitee relationship absent that requirement. Compare Sussman v. American Sur. Co., supra, with Renschler v. Pizano, $329 \mathrm{~Pa}$ 249, 198 Atl. 33 (1938), and Orth v. Consumers Gas Co., $280 \mathrm{~Pa}$. 118, 124 Atl. 296 (1924) (Moschzisker, C.J.). In Hendrix it was not necessary to reach the issue as to what the consequences of the insured's failure to notify the insurer of the third party's amendment were, and the court did not discuss the issue, because the third party's allegations were partly within the policy even before the amendment. Employers Mut. Liab. Ins. Co. v. Hendrix, 199 F.2d 53, 56 (4th Cir. 1952).

62 On remand the propriety and reasonableness of the settlement were to be at issue, and apparently the insured was to have the burden of proof. The court was careful not to require a trial on the merits of third parties' claim. Yet placing the burden of showing reasonableness on the insured would go far toward undermining avoidance of a trial on the merits, unless the court was primarily concerned with the fact that damages for both slander and personal injury, which apparently was slight, were included in the settlement and under the facts of this case the burden switched to the insured after the insurer had shown prima facie unreasonableness. 
quired the insurer to defend, it is difficult to see what consideration is offered to the insured for accepting a nonwaiver agreement.. ${ }^{53}$ Indeed, conducting his own defense might be to the insured's advantage. If he settled, for example, he might be able to show more easily that the grounds of the settlement were within policy coverage than if the insurer had defended and developed the facts. The ethical problem is posed most sharply by the argument that at a time when an attorney, retained by the insurer but representing the insured, advises the insured to agree to a nonwaiver agreement or reservation of rights, the attorney may very well be advising the insured against his best interests. Canon Six of the American Bar Association's Canons of Ethics states, among other things, that "it is unprofessional to represent conflicting interests, except by express consent of all concerned given after a full disclosure of the facts." 54 While the insurance policy itself might constitute the insured's consent to be represented by the insurer's attorney ${ }^{55}$ it could hardly be said that the policy contains a full disclosure of the facts. Moreover, it is questionable whether the insurer's attorney could make a full disclosure of the range of possible consequences and probabilities such that a layman could give informed consent.

Although this type of problem does not seem to be explicitly recognized in any rule of law affecting the rights of the insured and the insurer, it may partially explain the strictness with which the courts interpret nonwaiver agreements and notices of a reservation of rights. ${ }^{58}$

\section{The Reasonable Investigation Rule}

Cases in which the third party's complaint on its face is outside the policy have not yet been considered. The general rule would categorically

53 See, e.g., Magoun v. Liberty Mut. Ins. Co., 346 Mass. 677, 195 N.E.2d 514 (1964). In Newcomb v. Meiss, 263 Minn. 315, 116 N.W.2d 593 (1962), an insurer's attorney defended the insured against a claim of negligence under both a nonwaiver agreement and a reservation of rights. On appeal, the insurer's attorney unsuccessfully urged as grounds for reversal of a judgment against the insured the trial judge's refusal to instruct the jury on the issue of an intentional tort His theory apparently was that if the insured were found liable for an intentional tort, he could not also be found negligent. The attorney explained that his apparent sacrifice of the insured's interests to the insurer's was illusory since the statute of limitations for actions for intentional tort had run. But the court observed that the trial court might have permitted an amendment to the complaint under the circumstances.

If the insurer's attorney had prevailed, it is difficult to see how the insurer could have set up the prior judgment of intentional tort as a defense to an action on the policy, for there appears to be no consideration for the nonwaiver agreement since there was no question of the insurer's defense obligation. Unless the reservation of rights protected the insurer, it might then have been estopped to raise the defense of noncoverage. Therefore, the insurer might have been in a better position not defending. See Great Am. Ins. Co. v. Ratliff, 242 F. Supp. 983 (E.D. Ark. 1965).

64 ABA, Canons of Professional and Judictal Etaics 3 (1957).

55 See ABA, Opinions of the Committee on Professional Ethics and GrievANCES, Op. no. 282, at 591 (1957), reprinted with a comment in Persig, Cases on Professional Responsibility 168 (1965).

56 See Henry v. Johnson, 191 Kan. 369, 381 P.2d 538 (1963) (letter purporting to reserve rights of insurer while it moved to vacate a judgment against the insured held ineffective); Hawkeye Cas. Co. v. Stoker, 154 Neb. 466, 48 N.W.2d 623 (1951) (nonwaiver agreement held premised on doubt as to coverage and therefore ineffec- 
deny that the insurer had any duty to defend in these cases, even if the true facts were such that a more accurately framed complaint would be within the policy. ${ }^{57}$ In response to such a case another rule has been adopted in a few jurisdictions. That rule requires the insurer to conduct a reasonable investigation into the facts before disclaiming a duty to defend, unless it is willing to run the risk that a court would later charge it for defense costs after determining that the actual facts were within coverage. ${ }^{58}$

The reasonable investigation rule has been roundly criticized as an unjustified departure from the insurance contract. ${ }^{59}$ The argument against the rule runs as follows. According to the standard duty to defend provision, the insurer agrees to defend any suit against the insured "alleging such injury." "Such" refers to the description of injuries liability for which is indemnified in the primary coverage provision. There is no mention of any bearing that the actual facts or the merits of the third party's claim are to have on the duty to defend. Indeed, the provision emphasizes that only the allegations are controlling by including the unnecessary clause "even if such suit is groundless, false or fraudulent." Ordinarily, the argument would conclude, where a contract is this clear courts would feel constrained not to substitute their private notions of fair dealing for the parties' agreed bargain.60

\section{Construction of the Duty To Defend Provision}

But this judicial restraint need not be accepted as absolute. For many types of coverage, the insurance buyer has in reality no opportunity to negotiate over the terms of the contract, since terms are standardized.

tive when insurer disclaimed coverage completely and instituted action for declaratory judgment); Welch, Reservation of Rights and Declaratory Judgments, 1954 INS. L.J. 65; Note, Insurance Company's Dilemna: Defending Actions Against the Assured, 2 STAN. L. REv. 383, 384-88 (1950).

57 E.g., Travelers Ins. Co. v. Newsom, 352 S.W.2d 888 (Tex. 1961).

58 See cases cited in note 80 infra; text accompanying notes 80-84 infra.

59 See, e.g., Loftin v. United States Fire Ins. Co., 106 Ga. App. 287, 297, 127 S.E.2d 53, 60 (1962) (dissenting opinion) ; Travelers Ins. Co. v. Newsom, 352 S.W.2d 888 (Tex. 1961). See also Cahoon, Company's Duty To Defend-Recent Developments, 1961 INs. L.J. 151.

60 "It is well-settled that words or terms in an insurance policy, like the words or terms used in any other contract, are to be construed according to their plain, ordinary and accepted sense in the common speech of man unless it appears from the policy that a different meaning is intended." Ness v. National Indem. Co., $247 \mathrm{~F}$. Supp. 944, 948 (Alaska 1965). (Emphasis added.)

The argument might also include a defense of the reasonableness of the provision as written. It is reasonable that the insurer not be "required to defend if it would not be held bound to indemnify the defendant in the action if the plaintiff prevailed upon the allegations of the declaration." Fessenden School, Inc. v. American Mut. Liab. Ins. Co., 289 Mass. 124, 130, 193 N.E. 558, 561 (1935). Were the scheme of defense coverage otherwise, the insurer would have to anticipate amendments to the pleadings or variances and would, in effect, be forced to place itself in a better position to know the nature of the third party's claim than the third party himself. Cf. Roos, supro note 12, at 209-11. Even if the third party did amend, it would be time enough then for the duty to attach. However, this argument depends for much of its force on strict pleading requirements which might be an assumption contrary to fact. See text accompanying notes 4-6 supra. 
The buyer must either accede to these terms or do without insurance altogether. An agreement entered into in such circumstances has been denominated an adhesion contract by one court ${ }^{61}$ which concluded that the disparity of the parties' bargaining power made it appropriate to relieve the weaker party-the consumer-from the operation of those contract terms which exhibited overreaching by the stronger party. The question is whether the adhesive qualities of a liability insurance policy justify the degree of departure from the duty to defend provision necessary to support the reasonable investigation rule. ${ }^{62}$ To identify those adhesive qualities, it is necessary to probe the bargaining context and the workings of the duty to defend provision. To this end, a distinction will be made between the objectives of the insurer, the expectations of the insured and the wording of the policy. Examining the interaction of the three factors helps to expose the degree of adhesiveness, which in turn appears to be the unarticulated underpinning of the reasonable investigation rule.

As to the insured's expectations, it is safe to assume that if the ordinary insurance consumer had thought about them, his expectations would be that the insurer would defend him whenever there was a threat of liability to him and the threat was based on facts within the policy. The insured probably would be surprised at the suggestion that defense coverage might turn on the pleading rules of the court that a third party chose or on how the third party's attorney decided to write the complaint. In some cases the insured might think in terms of his own conduct. The bar owner, for example, might well think that he is insulated from any legal expense arising from injuries to patrons so long as he personally does not intentionally injure someone or tell an employee to do so. ${ }^{63}$ To him the possibility of an ambitious claimant who would begin a lawsuit with a charge of intentional injury for the sake of a favorable bargaining position and later be willing to abandon that charge for one of simple negligence might not occur; or if the possibility did occur the insured might not pause to consider whether it would be fatal to part of his insurance coverage. In short, the limits of the phrase "suits alleging such injury," prepared by lawyers, defended by lawyers and authoritatively interpreted by lawyers, are probably not appreciated by the lay insured. And even the more sophisticated insured has no choice in the matter, since the provision is standard.

The insurer's objectives, which are deducible from its written contract, also deviate from the duty to defend provision, but in a different way. The insurer's purpose is to protect its own interest by assuring itself of a vigorous defense in those cases in which it would be required to pay any judgment suffered by the insured. To be safe it also intends and obligates

61 See Henningsen v. Bloomfield Motors, Inc., 32 N.J. 358, 161 A.2d 69 (1960); UNIFORM COMMERCIAL CODE \$2-302, comment.

62 See also First Ins. Co. v. Chapman, 255 F.2d 49, 53 (9th Cir. 1965) (dissent); Note, 5 Santa Clara Law. 60 (1964).

63 See McGettrick v. Fidelity \& Cas. Co., 264 F.2d 883, 886 (2d Cir. 1959) (dictum); Loftin v. United States Fire Ins. Co., 106 Ga. App. 287, 295, 127 S.E.2d 53,58 (1962) (dictum). 
itself to defend groundless, false and fraudulent suits in which there is a low probability of losing but in which the insurer has a contractual obligation to pay off if liability results. ${ }^{6 t}$ The most probable reason why this intention is linked with the third party's allegations is that those allegations for the most part accurately predict the grounds of any judgment the third party might gain. However, for allegations to be an accurate mode of predicting the grounds of any judgment, a pleading system in which the allegations would always pose and limit the factual and legal conclusions that a judgment could embody would have to exist. But no pleading system operates with sufficient precision to predict accurately insurance coverage. The duty to defend provision recognizes this lack of precision by including groundless suits within its scope. Yet the general rule presupposes the existence of this nonexistent pleading model. Even if the test of measuring the duty to defend solely by reference to the third party's allegations is implicit in the words "alleging such injury," the test does not give exhaustive effect to the insurer's objectives. This shortcoming in the test becomes apparent when a pleading system is posited which requires no factual allegations and provides for notice of the factual basis of a claim or defense only by such depositions as either party wanted to take. ${ }^{65}$ The duty to defend provision would be rendered meaningless, yet there would be no doubt that the insurer's objectives would remain the same. The insurer would probably exercise discretion and offer the benefit of its defense to the insured in those cases which as far as it could predict would result in a judgment within the primary coverage. In fact, it would seem that the insurer exercises this same discretion under existing pleading systems, for there are relatively few reported cases in which the insurer has refused to defend a suit that has proceeded to a judgment which it was then obligated to pay. ${ }^{66}$ What is happening, then, is that the insurer can use the discrepancy between its objectives and the language of the duty to defend provision to withhold the benefit of a defense from the insured when it appears that the third party will lose and the third party's complaint on its face is outside the policy, even though the factual basis of the third party's claim is within the policy; and the insurer can use this discrepancy to minimize its costs if it does inaccurately predict that any money judgment the third party gains will be outside the policy.

64 See Comment, 10 VIrL. L. Rev. 558 (1965).

65 Compulsory arbitration procedures approach the hypothetical pleading system posited, for after a case has been referred to arbitration there is no opportunity or need for amendments to the pleadings. See Comment, Compulsory Arbitration, 2 VII. L. REv. 529 (1957). See also 113 U. PA. L. Rev. 1117, 1121 n.34 (1965). Another analogue is suggested by a recent Kansas case. In Henry v. Johnson, 191 Kan. 369, 381 P.2d 546 (1963) (4 to 3 decision), the court held in the alternative that even though, contrary to a policy requirement, the insured had failed to forward the third party's complaint to the insurer, the investigation that the insurer had in fact conducted supplied sufficient notice to bind the insurer. See also Watters $v$. American Ins. Co., 185 Cal. App. 2d 776, 8 Cal. Rptr. 665 (1960) (insurer disclaimed before third party's complaint was filed).

${ }^{66}$ Journal Pub. Co. v. General Cas. Co., 210 F.2d 202 (9th Cir. 1954) ; Kelly v. United States Fid. \& Guar. Co., 76 So. 2d 116 (La. Ct. App. 1954). 
Ordinarily where one party has this sort of advantage, a court will not intervene. Both parties are held to their bargain. But as Professor Morris has pointed out in another context, there is a striking contrast between the sophistication of a nineteenth century entrepreneur having marine insurance written and that of an automobile driver purchasing liability insurance. ${ }^{67}$ In fact, if one were forced to make comparisons, the concept of a contract being the result of two parties bargaining until they reach an agreement that can be set down in a memorandum would not match up very closely with a typical insurance purchase. Rather the insurance policy is closer to the so-called "adhesion contract." 68 Where a term of a contract for a consumer product is uniform and in application "unconscionable" due to the superior bargaining power of the seller so that an individual consumer must either "adhere" to the unconscionable term or do without the product, courts as a matter of public policy might not enforce the term. ${ }^{69}$ The liability insurance policy, however, falls somewhere between an adhesion contract, in this its most pejorative sense, ${ }^{\mathbf{7 0}}$ and a normal contract, because not all of the disfavored adhesion elements are present. Conspicuously missing is unconscionableness, unless it can be equated with isolated disappointment or hardship. Furthermore, while uniformity resulting from oligopolistic bargaining power might in general be undesirable, uniformity in insurance carriers' terms has virtue, for it is only by pooling data drawn from identical insurance contracts that insurers can most accurately predict risks and set rates accordingly. ${ }^{71}$

But the force of the adhesion doctrine is not completely spent by the above considerations. The fact remains that the insured is probably misled. The discrepancy between the results that the technical term "alleging" purports to dictate and the insured's expectations works to his disadvantage. ${ }^{72}$ Even assuming the insured has greater than average legal

67 Morris, supra note 15 , at $925-28$.

68 See Ehrenzweig, Adhesion Contracts in the Conflict of Lazes, 53 Colum. I. Rev. 1072 (1953); Kessler, Forces Shaping the Insurance Contract, 1954 INs. L.J. 151. 69 See Henningsen v. Bloomfield Motors, Inc., 32 N.J. 358, 161 A.2d 69 (1960).

70 That is, the Henningsen sense. In Henningsen, supra note 69 , the court held an automobile manufacturer's disclaimer of liability beyond the minimal amount assumed in a warranty insufficient to bar a personal injury claim. In another sense, the theory of an adhesion contract may underlie the familiar canon of construction that any ambiguities in an insurance contract are resolved against the insurer. However, these two senses of the term may tend to merge. See 6A CoRBIN, ConTracts $\$ 1376$, at 21 (1962): "Standardized contracts, such as insurance policies, drafted by powerful commercial units and put before individuals on the 'accept this or get nothing basis, are carefully scrutinized by the courts for the purpose of avoiding enforcement of 'unconscionable' clauses. At times this avoidance is effected by a process of pseudo 'interpretation'; at other times by refusing to permit successful 'overreaching.' "

71 Compare Kulp, The Rate-Making Process in Property and Casualty Insurance -Goals, Technics, and Limits, 15 LAw \& ConTeMr. ProB. 493 (1950). It has also been suggested that standardization promotes consumer understanding of the policy. Hedges, Improving Property and Casualty Insurance Coverage, 15 LAW \& CoNTEMP. Prob. 352, 357-61 (1950).

${ }^{72}$ Cf. Meyer, Contracts of Adhesion and the Doctrine of Fundamental Breach, 50. VA. L. REv. 1178, 1187 (1964): "To the extent that these clauses anticipate future controversy and provide a machinery for settling disputes, they are in the best tradition of legal planning. . . When not bargained for, however, they invite disfavor as an attempt by one party to make himself judge in his own case." 
sophistication and therefore is not misled, he still has no choice in buying insurance; he must sacrifice full defense coverage to his primary need for indemnity. The objectionable feature of this lack of choice is that the insurer is in no way hurt by this discrepancy. Indeed, the insurer benefits for it can fulfill its objectives by offering to defend in cases where the risk of a sizable liability within the policy is high. The insured gains a corresponding benefit when the insurer does actually defend, even if under a reservation of rights; but relative to his expectations the correspondence is erratic.

Judicial opinions in cases departing from the general rule have fared badly in articulating a rationale for the departure and indeed have been notable for the absence of any thorough going justification. One of the earliest courts which was willing to look beyond the third party's allegations apparently thought that any construction of the policy which did not require the insurer to defend suits against the insured which could result in liability within the policy was simply unfair. ${ }^{73}$ Moreover, there is some indication in the opinion that the court failed to distinguish between the insurer's obligation to indemnify under the primary coverage provision and its obligation to defend under the duty to defend provision and thought that the former could not apply without the latter. ${ }^{74}$

More recently, in Milliken v. Fidelity \& Cas. Co., ${ }^{75}$ a federal court applied the reasonable investigation rule, even though the state whose law it was Erie-bound to follow had adopted the general rule. The one fact the court considered crucial was that after the third party had instituted his action in the state court, the insured defendant removed to federal court. The court then stated that since the state courts had only passed on insurers' duty to defend state suits, this case was one of first impression because the state courts required fact pleading and the federal courts notice pleading. ${ }^{76}$ Since "the pleadings are not a rigid and unchangeable

73 Hardware Mut Cas. Co. v. Hilderbrandt, 119 F.2d 291 (10th Cir. 1941) (unanimous decision for insurer became 2 to 1 decision for insured after rehearing).

74 Id. at 299.

75338 F.2d 35 (10th Cir. 1964).

${ }^{76} I d$. at 39-40. But cf. United Serv. Life Ins. Co. v. Delaney, 328 F.2d 483 (5th Cir.), cert. denied, 377 U.S. 973 (1964) (federal court to abstain from interpreting term in an insurance policy until state court passes on question, where state law was uncertain). Case law development in Pennsylvania lends support to the Milliken court's analysis of the Erie problem. Precedent in Pennsylvania was similar to that in Kansas, the state of Milliken's forum. Compare Wilson v. Maryland Cas. Co., $377 \mathrm{~Pa}$ 588, 105 A.2d 304 (1954) (third party's complaint in state court fixed claim outside the policy: no duty to defend), 103 U. PA. L. REv. 445 (1954), with Leonard v. Maryland Cas. Co., 158 Kan. 263, 146 P.2d 378 (1944). In Cadwallader v. New Amsterdam Cas. Co., $396 \mathrm{~Pa}$. 582, 152 A.2d 484 (1959), the Pennsylvania Supreme Court seemed receptive, in dictum, to distinguishing the Wilson case on the grounds that the third party's action against the insured in Cadwallader was instituted in federal court which had more liberal pleading rules. Id. at $591,152 \mathrm{~A} .2 \mathrm{~d}$ at 489 . In Pittsburgh Plate Glass Co. v. Fidelity \& Cas. Co., 281 F.2d 538 (3d Cir. 1960), the federal court in applying Pennsylvania law reasoned along the lines of Milliken but did not have to reach explicitly the question as to whether a reasonable investigation rule applied. Milliken then is similar to Pittsburgh Plate Glass without Cadwallader. 
blueprint of the rights of the parties," 77 and since the duty to defend could "attach at any stage in the litigation," 78 the court concluded that any "facts, extraneous to the allegations of the pleadings, which, if proved, make out a case against the insurer [sic] that is covered by the policy and which either are actually brought to the insurer's attention or could have been discovered by it through a reasonable investigation" determine the insurer's duty to defend. ${ }^{79}$ Even granting the plasticity of federal pleading, the court failed to answer explicitly why it could hold that the insurer has a duty to defend against complaints clearly outside the policy when the insurance contract provides only that the duty attaches in suits "alleging such injury."

\section{How the Reasonable Investigation Rule Operates}

As the reasonable investigtaion rule is now developing, the requirement of an investigation tends to fulfill the insured's expectations, for the net result is that the insurer's liability for the insured's defense costs is decided on the basis of the actual facts. If the insurer relied solely on the third party's allegations to conclude that it had no duty to defend, courts so far have enforced this required investigation by supplying a judicial finding of fact for the investigation that the insurer did not make. ${ }^{80}$ If the finding of fact is within the policy, the insurer must reimburse the insured for the reasonable expense of his defense. Thus, the insurer which does not investigate is precluded from maintaining that an investigation could just as reasonably have concluded that the facts were outside

77 Quoting from Harbin v. Assurance Co. of America, 308 F.2d 748, 750 (10th Cir. 1962).

78 Milliken v. Fidelity \& Cas. Co., 338 F.2d 35, 40 (10th Cir. 1964).

79 Ibid.

80 Ibid.; American Motorists Ins. Co. v. Southwestern Greyhound Lines, Inc. 283 F.2d 648 (10th Cir. 1960); McGettrick v. Fidelity \& Cas. Co., 264 F.2d 883 (2d Cir. 1959); Loftin v. United States Fire Ins. Co., 106 Ga. App. 287, 127 S.E.2d 53 (1962) ; Pendleton v. Pan. Am. Fire Cas. Co., 317 F.2d 96 (10th Cir.) (dictum), order modified, 326 F.2d 760 (10th Cir. 1964), cert. denied, 375 U.S. 905 (1963); Harbin v. Assurance Co. of America, 308 F.2d 748 (10th Cir. 1962) (semble); Travelers Ins. Co. v. Newsom, 352 S.W.2d 888, 896 (Tex. 1961) (dissenting opinion). In other cases the facts were known to the insurer; therefore the question of an investigation was not reached. Hardware Mut. Cas. Co. v. Hilderbrandt, 119 F.2d 291 (10th Cir. 1941) ; Hagen Supply Corp. v. Iowa Nat'l Mut. Ins. Co., 331 F.2d 199 (8th Cir. 1964) (dictum); see Albuquerque Gravel Prods. Co. v. American Employers Ins. Co., 282 F.2d 218 (10th Cir. 1960) (insured failed to prove facts were within the policy); cf. State ex rel. Inter-State Oil Co. v. Bland, 354 Mo. 622,190 S.W.2d 277 (1945) (policy worded differently but case did not turn on difference); Marshall's U.S. Auto Supply, Inc. v. Maryland Cas. Co., 354 Mo. 455, 189 S.W.2d 529 (1945) (dictum) (policy worded differently). See also Pittsburgh Plate Glass Co. v. Fidelity \& Cas. Co., 281 F.2d 538 (3d Cir. 1960); University Club v. American Mut. Liab. Ins. Co., $124 \mathrm{~Pa}$. Super. 480, 189 Atl. 534 (1937). In still other cases the rule has been formulated in terms of whether the insurer knew or was informed by the insured of the actual facts. Crum v. Anchor Cas. Co., 264 Minn. 378, 119 N.W.2d 703 (1963) ; Bituminous Cas. Corp. v. Travelers Ins. Co., 122 F. Supp. 197 (D. Minn. 1954). This last formulation amounts to a requirement of a reasonable investigation, since the insurer could not rely on what the insured says the actual facts are and yet if the insured was correct in what he said the facts were, he would recover his defense costs. 
the policy. ${ }^{81}$ It is uncertain, however, whether the insurer is still so precluded if it comes forward with proof that it actually conducted an investigation that at the time tended to show that the facts were outside the policy, when the insured is prepared to show that the actual facts were within the policy. ${ }^{82}$ One court apparently carried that preciusion over to such a case in holding that it was not error to exclude evidence which would have tended to show that the insurer had acted reasonably in concluding that facts dehors the third party's complaint were outside the policy. ${ }^{83}$ Instead, the question for the fact finder was what happened, to which question the excluded evidence was not pertinent. ${ }^{84}$

That case, American Motorists Ins. Co. v. Southwestern Greyhound Lines, Inc., ${ }^{85}$ suggests that in practice the reasonable investigation rule is of limited utility because it does not provide the insurer with any fixed guide for its conduct. In Harbin v. Assurance Co. of America ${ }^{86}$ the Court of Appeals for the Tenth Circuit tried to meet this limitation consistently with American by adopting what amounts to a wait and see modification of the reasonable investigation rule. Policy coverage in Harbin turned on whether the insured had committed an intentional tort. Since no amount of pretrial investigation could enable the insurer to predict with any certainty what a trier of fact would find on the issue of intent, the court concluded that the insurer need not defend as of the time the third party's complaint was filed and indeed could not defend initially because of a conflict of interest. The implication in the case was that the duty to defend could conceivably arise if the third party's claim changed so as to appear to be within the policy. ${ }^{87}$

81 See, e.g., McGettrick.v. Fidelity \& Cas. Co., 264 F.2d 883, 886 (2d Cir. 1959) : "Since the insurance company had not made the required investigation, the only possible substitute for what its investigation would have shown is the jury's own finding as to the merits of North's [the third party's] claim."

82 Compare American Motorists Ins. Co. v. Southwestern Greyhound Lines, Inc., 283 F.2d 648 (10th Cir. 1960), with Harbin v. Assurance Co. of America, 308 F.2d 748 (10th Cir. 1962).

83 American Motorists Ins. Co. v. Southwestern Greyhound Lines, Inc., supra note 82. The factual issue in the case was whether the third party, a bus passenger, was injured while alighting from a bus in a bus station and therefore within a policy exclusion. The excluded evidence was the third party's complaint, her depositions and those of another witness, and a judgment dismissing the bus station as a defendant -all from the third party's action against the insured and all offered to show that the insurer had reasonably concluded that the facts were within the exclusion and thus outside the policy.

84 Ibid. At trial in the American case the jury apparently accepted the testimony of some Greyhound (the insured) employees that the third party was injured not while alighting from the bus. After the bus station had been dismissed as a defendant in the third party's action against Greyhound, Greyhound settled. Therefore, there was no prior finding of fact binding the American court, see notes 28-34 stipra, and accompanying text, unless the bus station's dismissal was on the grounds that any injury sustained by the third party, the passenger, did not occur on the bus station's platform and that dismissal could be taken as binding on the third party and the insured. This possibility was not discussed by the American court. Cf. Leonardi v. Standard Acc. Ins. Co., 212 F.2d 887 (2d Cir. 1954).

85283 F.2d 648 (10th Cir. 1960).

86308 F.2d 748 (10th Cir. 1962).

87 The implication is by no means clear. The inference is drawn from the fact that the court was careful to limit its judgment to the insurer's duty to defend and 
The procedural posture helps explain the decision. The third party had filed a complaint alleging that the insured intentionally assaulted him. The insured's position was that at most he had been negligent. In doubt as to whether to defend, the insurer brought an action against the insured for a declaratory judgment. While a declaratory judgment is an effective device either for interpreting how provisions of an insurance policy apply to a given set of facts or for determining whether the insured has breached a requirement of the policy, it is unwieldy where the dilemma was caused by a disputed issue of fact. ${ }^{88}$ The court was understandably reluctant to second-guess the outcome of the third party's action, for the issue was not what the insured's state of mind actually was but rather what the trier of fact in the third party's action would determine was the insured's state of mind. If the court had resolved this issue of fact between the insured and the insurer, res judicata would have barred retrying the issue between them if the third party's action had come out the other way and recovery on the policy were at issue. ${ }^{89}$ The court concluded that the insurer did not have a duty to defend when the complaint was filed.90

Two unnecessarily different versions of the reasonable investigation rule might seem to be emerging in the Tenth Circuit. In Harbin, by implication, a wait and see modification was adopted. Yet two years earlier in American, another Tenth Circuit case, which the Harbin court decided was distinguishable because of its procedural posture and hence not con-

did not include any adjudication of the insurer's liability for any judgment that the insured might suffer. The court further limited its judgment by saying only that the insurer "is not obligated at this time to defend . . ." Id. at 750. (Emphasis added.)

88 Compare Harbin v. Assurance Co. of America, 308 F.2d 748 (10th Cir. 1962), with Bennett v. Fidelity \& Cas. Co., 132 So. 2d 788 (Fla. Dist. Ct. App. 1961) (issue was whether allegations of injury from a dammed drainage ditch which flooded in a rainstorm were allegations of an "accidental injury" within the meaning of the policy).

${ }^{89}$ See Green v. Aetna Ins. Co., 349 F.2d 919 (5th Cir. 1965) (court ruled on the insurer's duty to defend by applying the general rule but refused to rule on primary coverage in advance of state trial determination); Continental Cas. Co. v. Reinhardt, 247 F. Supp. 173 (D. Ore. 1965). But see Stout v. Grain Dealers Mut. Ins. Co., 201 F. Supp. 647 (M.D.N.C.), aff'd, 307 F.2d 521 (4th Cir. 1962). Recognizing that coverage might be determined finally in the federal action for a declaratory judgment, the third party might feel forced to present his case in that action. Therefore, in effect, the state court plaintiff would be deprived of his choice of forum. See Green v. Aetna Ins. Co., supra. Under the general rule, there is no necessity for joining the third party in an action for declaratory judgment to determine the insurer's duty to defend, for a direct action on the policy if and when one lies would be sufficient and would be the most efficient utilization of courtroom time. See Hartford Acc. \& Indem. Co. v. Williamson, 216 A.2d 635 (Conn. 1966). The insurer might be able to accomplish the same goal, i.e., having one trial with all three parties, by intervening in the third party's action against the insured under, for example, Federal Rule of Civil Procedure 24. See Knapp v. Hankins, 106 F. Supp. 43 (E.D. Ill. 1952); see generally Comment, Estoppel, Third Party Practice, and Insurer's Defenses, $19 \mathrm{U}$. CHI. L. REv. 546 (1952). The infrequency with which this type of third party practice appears in reports suggests that insurers are reluctant to identify themselves as a possible real party in interest because of jury prejudice.

90 Harbin v. Assurance Co. of America, 308 F.2d 748 (10th Cir. 1962). See generally Note, Use of the Declaratory Judgment To Determine a Liability Insurer's Duty To Defend-Conflict of Interests, 41 IND. L.J. 87 (1965). 
trolling, ${ }^{91}$ the insurer was held to what seemed to be as difficult a prediction as the one the Harbin court rejected..$^{22}$ The third party's allegations were outside the policy and the insurer refused to defend, whereupon the insured settled. In an action on the policy for the amount of the settlement and defense costs, the actual facts were determined from conflicting testimony and the court made an all or nothing decision on the insurer's duty to defend. Since a reasonable investigation could have-not "would necessarily have"-uncovered the actual facts, which were within the policy, the insurer was liable for defense costs as well as the amount of settlement.93 If the American court had taken an approach wholly consistent with Harbin (assuming contrary to fact that American was subsequent to Harbin), it might have been forced to decide that the insurer did not have to defend until it appeared that a trier of fact would have found that the facts were within the policy.94

The key to reconciling the two cases would seem to be the distinction made earlier in the context of criticism of the rule requiring an insurer to defend an ambiguous or multiple count complaint only until the third party's claim is confined to grounds outside the policy. ${ }^{95}$ The duty to defend can be broken down into two discrete components: the privilege of controlling the actual defense and the obligation to pay defense costs. The Harbin opinion can be read as saying no more than that the insurer could not take control of the insured's defense unless it was willing to waive any policy defense of non-coverage that it might have. The opinion would seem not to foreclose the possibility that the insurer might still be charged with all defense costs if in retrospect it could be concluded that a reasonable investigation could have, and therefore should have, uncovered

91 The Harbin court said Anerican was "not controlling because ... the action sought to impose liability on the insurer after the facts had been established. . . ." 308 F.2d at 749. But it has been pointed out that the facts in American "were not established; they were in dispute at the time the insurer refused to defend the action, just as they were in Harbin." Comment, 3 Natural Resources J. 185, 189 (1963). The operative word in this quotation from Harbin then must be "after." It also appears that if the insurer had actually defended in Americant, it would have faced as much of a conflict of interest as the insurer would have in Harbin. The conflict though would seem to be a moot point because the insurer would be estopped from raising a defense of noncoverage, see, e.g., Pendleton v. Pan Am. Fire Cas. Co., 317 F.2d 96 (10th Cir.), cert. denied, 375 U.S. 905 (1963), order modified, 326 F.2d 760 (10th Cir. 1964), unless it defended under a reservation of rights or nonwaiver agreement, in which event it still might have difficulty in establishing a defense of noncoverage based on facts outside the policy, cf. Newcomb v. Meiss, 263 Minn. 315, 116 N.W.2d 593 (1962). But see Loftin v. United States Fire Ins. Co., $106 \mathrm{Ga}$. App. 287, 293, 127 S.E.2d 53, 59 (1962) (dictum).

92 See notes 83-84 supra.

93 Harbin v. Assurance Co. of America, 308 F.2d 748 (10th Cir. 1962).

94 If the attachment of the duty to defend does depend on the timing of an apparent change in the third party's claim, an administrative uncertainty would seem to remain. If such a change in the third party's claim did become apparent through, for example, an amendment in the pleadings to conform to the proof, it is unclear whether there would be a midtrial change of counsel, an allocation of defense costs of some sort between insurer and insured or some combination of the two.

95 See text accompanying notes 21-23 supra. 
facts within the policy. ${ }^{96}$ If that possibility is open, Harbin and American are consistent.

If the two cases are read together in this way, it may be objected that charging the insurer with knowledge of facts within the policy as a court would later find them is not only in some cases an impossible standard of conduct to which to hold the insurer but also might raise the insurer's operating costs substantially more than the benefits to the insured are worth. The actual expense of conducting a thorough investigation every time an insured maintains that, contrary to a third party's allegations, the factual basis of the threat of liability is within policy coverage could be expected to raise costs. ${ }^{97}$ While there is always a possibility of "accidental" waiver or estoppel, the reasonable investigation rule might increase the probability and thus increase costs also. The very proliferation of the insurer's representatives coming into contact with the insured-claim investigators, the local sales agent and attorneys retained by the insurerincreases the probability that one of them might mislead the insured so that the insurer would be estopped from raising policy defenses. Moreover, time spent actually investigating and arriving at a decision as to whether to defend might have the same effect, if the insured were left right before trial without counsel or the benefit of an investigator or negotiator. ${ }^{98}$

This objection to the reasonable investigation rule based on increased costs, however, might be more imagined than real. The reasonable investigation rule creates no incentive for the insurer to increase investigation costs over and above those it already assumes to further its objectives.

${ }_{96}$ This reading of Harbin is not an easy one, but neither are any others. On the one hand, the court said that American was not controlling. It also said: "The ultimate question of the insurer's liability is not now before us as it was in Tenth Circuit cases [including American] on which the insureds rely. If it should be determined that the injuries for which the plaintiff [herein referred to as the third party] seeks recovery in the state action were covered by the policy and not within its exclusionary provisions, the insurer is liable to the insureds under the policy." $308 \mathrm{~F} .2 \mathrm{~d}$ at 750 . This passage has been read as referring only to the insurer's liability for a judgment within the policy and not to its obligation to pay defense costs. Comment, 3 NaruraI RESOURCES J. 185, 192 (1963). Yet it seems just as susceptible to the reading that the reference is to defense costs "under the policy" as well as the judgment, particularly since the court purported to be acting in accord with American. On the other hand, it seems unlikely that the court would have intended to mean, without making an explicit distinction between the insurer's obligation to pay defense costs and its right to assume control of the insured's defense, that although the insurer was not obligated to defend "at this time," it might have to pay defense costs. The real answer probably is that the court did not address itself to the problem because it was unlikely to arise. A third party complaint had been filed against the insurer by the insured in the state action, and the insured had already been convicted of criminal assault, Comment, 3 Natural Resources J. 185, 186 (1963) (citing the record of which action it is unclear and not indicating whether the insured pleaded guilty or whether his pleading was relevant).

97 Moreover, to avoid the necessity of consulting a lawyer at an early stage on questions which might be beyond the competence of a lay claims investigator, see Donaldson, Casualty Clain Practice 398-402 (1964); Magarick, Successfoul Handing of Casualty Clatms 193-202 (1955), and which might increase in frequency, insurers might be more willing than otherwise to compromise claims, $c f$. Hermann, Legal Costs to Insurance Companies and How They Can be Reduced, 1964 INS. L.J. 137, reprinted in 6 LAW OFFICE ECONOMICS AND MANAGEMENT 201 (1965). 98 See Morris, Waiver and Estoppel in Insurance Policy Litigation, 105 U. PA. L. REv. 925, 942-43 (1957). 
The assumption here is that, absent the reasonable investigation rule, the insurer would fully investigate and vigorously defend any suit against the insured, regardless of the allegations, if there were a high probability that the suit would proceed to a large judgment within the policy. ${ }^{99}$ Even with the reasonable investigation rule, the insurer could be expected not to investigate fully or to defend a suit against the insured which, although perhaps based on facts within the policy, has a low probability of proceeding to a sizable judgment within the policy. The reasonable investigation rule therefore serves not so much as a rule of conduct for the insurer to follow as a method of fulfilling the insured's expectations. Some of the difficulties in administering the rule are attributable to the fact that while courts feel compelled to talk about the former function of the rule, their major concern is in implementing the latter.

Costs other than the expenses of the insurer's investigations-the cost of the insured's actual defense-are justifiable by an appeal to fairness. It seems better to have the costs of any quirks that might arise in a third party's suit absorbed by all rate payers evenly rather than by one insured. Furthermore, although it might appear unfair to require the insurer to decide whether to defend when the face of a third party's claim is outside the policy and when the insurer might be estopped if despite its defense the insured loses on grounds outside the policy, it still seems reasonable to place the burden on the insurer to make these hard decisions. Expertise, initially, resides with the insurer, and in a sense that expertise is part of what the insurer is marketing. Moreover, it is not facetious to suggest that the insurer have insurance for mistaken decisions in the sense that added costs be passed on to all consumers.

\section{A Syntresis}

When judicial approaches to the duty to defend, which are selected without regard to the different jurisdictions, are put together, they begin to fall into a coherent pattern. The pattern, of course, depends on the selection and is advanced here in the form of positive propositions only as a prediction of the direction case law development should and might take.100 (1) The Standard of the Defense Obligation: The insurer's duty to defend is determined by whether a third party's claim against the insured could potentially proceed to a judgment covered by the policy. If any part or any reading of the third party's allegations comes within the description of the insured's liabilities that the insurer agrees to pay, then the insurer

99 See text accompanying notes 64-66 supra.

100 The reasonable investigation rule is included in this synthesis because the insured who is abandoned by his insurer solely because of an idiosyncracy in a third party's pleadings or in the pleading premise of the policy itself is a sympathetic figure; and although the reasonable investigation rule is now a minority rule, as precedent grows it most probably will be relied upon to handle the relatively few cases to which it is applicable. See 7 WiLlISTON, CoNTRACTS 429 (3d ed. Jaeger 1963), in which a similar prediction is made, but in which it is suggested that the reasonable investigation rule would affect the insurer's approach to many more cases. 
has a defense obligation. ${ }^{101}$ The insurer has the same obligation if a "reasonable" 102 investigation does or would disclose facts within that description. (2) Consequences of the Obligation: Regardless of the nature of the third party's claim, if the insurer assumes the insured's defense, ${ }^{103}$ the insurer has fulfilled its defense obligation and it must pay the amount of judgment, ${ }^{104}$ unless it has effectively reserved the right to contest coverage by so notifying the insured. ${ }^{105}$ Conversely, if the insurer does not defend, its defense obligation, if it arises according to the above standard, is discharged by reimbursing the insured for his defense costs. Independently of whether the insurer must pay defense costs, ${ }^{106}$ it must pay the amount of the insured's legal obligation to the third party if it is based on facts within the description of coverage. If that legal obligation is in the form of a judgment, the insurer may not show that the legal obligation is outside the policy description by facts inconsistent with the findings of fact upon which the judgment was entered. ${ }^{107}$ If the insurer's legal obligation is in the form of a settlement, the insured must show that the settlement was on grounds within the description of coverage, unless the insurer had a defense obligation. ${ }^{108}$ If according to either the facts alleged or the facts

101 Cases cited note 9 supra.

102 "Reasonable" is here used as in American Motorists Ins. Co. v. Southwestern Greyhotund Lines, Inc., 283 F.2d 648 (10th Cir. 1960). An investigation is reasonable only if it finds the facts as a court later does. See notes 80-84 supra and accompanying text.

103 A temporary assumption of the defense will be treated as a complete assumption, unless the ground of the third party's claim that created the insurer's defense obligation was baseless and unless the insured was not prejudiced by the insurer's withdrawal. This formulation is a compromise based on the textual discussion accompanying notes 11-23 supra.

104 The insurer must pay only the amount of the judgment up to the policy dollar limits, unless the insurer's rejection of a prejudgment settlement offer for an amount within the policy dollar limits violated some duty the insurer owed the insured. See generally Gedeon v. State Farm Mut. Auto. Ins. Co., 342 F.2d 15 (3d Cir. 1965); Comunale v. Traders Gen. Ins. Co., 50 Cal. 2d 654, 358 P.2d 198 (1958); Keeton, Liability Insurance and Responsibility for Settlement, 67 HARv. L. REv. 1136 (1954); Note, Excess Liability: Reconsideration of California's Bad Faith Negligence Rule, 18 Stan. L. Rev. 475 (1966).

105 An effective reservation of rights or non-waiver agreement permits the insurer to raise the insured's non-cooperation or failure seasonably to notify as a defense to an action on the policy. However, it might be questioned whether a reservation of rights or nonwaiver agreement would permit the insurer to defend an action on the policy by proving facts inconsistent with those found by a court in determining the insured's legal obligation to the third party, since the insured would remain "legally obligated" to the third party for the reasons given and upon the facts found by a prior court no matter what the insurer is able to prove. Cf. Comment, $19 \mathrm{U}$. CHI. L. REv. 546, 549 (1952). If the insurer were permitted to prove facts inconsistent with the prior judgment, the insured would seem to be waiving more than the opportunity to raise waiver and estoppel against the insurer. He would also seem to be waiving policy coverage. See text accompanying notes $53-55$ sipra.

106 See notes 24-26 supra and accompanying text.

107 See notes 28-43 supra and accompanying text.

108 If the defense obligation is determined by the reasonable investigation rule, the insurer's liability for the settlement would seem automatic, since the same issue of fact would determine the insurer's duty to defend as well as its obligation to pay the settlement. 
which would have been found through reasonable investigation the third party's claim potentially could have proceeded to a judgment within the description of coverage, the insurer can avoid liability for the settled amount only by showing that the settlement must have been on grounds outside the policy. ${ }^{109}$

109 See notes 45-52 supra and accompanying text. 